\title{
IKK $\beta$ inhibitor in combination with bortezomib induces cytotoxicity in breast cancer cells
}

\author{
HIROMASA HIDESHIMA $^{1 *}$, YASUHIRO YOSHIDA ${ }^{1,2^{*}}$, HIROSHI IKEDA $^{1,3}$, MAYA HIDE $^{1}$, \\ AKINORI IWASAKI ${ }^{2},{\text { KENNETH C. } \text { ANDERSON }^{1} \text { and TERU HIDESHIMA }}^{1}$ \\ ${ }^{1}$ Department of Medical Oncology, Dana-Farber Cancer Institute, Boston, MA, USA; ${ }^{2}$ Department of Thoracic, \\ Endocrine and Pediatric Surgery, Faculty of Medicine, Fukuoka University, Jonan-ku, Fukuoka; \\ ${ }^{3}$ Department of Internal Medicine, Sapporo Medical University School of Medicine, \\ Chuo-ku, Sapporo 060-8543, Japan
}

Received October 30, 2013; Accepted December 2, 2013

DOI: 10.3892/ijo.2014.2273

\begin{abstract}
Bortezomib is a proteasome inhibitor with remarkable clinical antitumor activity in multiple myeloma (MM) and is under evaluation in clinical trials in various types of cancer including breast cancer. Although the initial rationale for its use in cancer treatment was the inhibition of NF- $\mathrm{KB}$ activity by blocking proteasomal degradation of I $\kappa \mathrm{B} \alpha$, direct evidence indicating inhibition of constitutive NF- $\mathrm{KB}$ activity by bortezomib in tumor cells in patients has not yet been reported. Moreover, recent studies have shown that bortezomib activates constitutive NF- $\mathrm{KB}$ activity via stimulating the canonical pathway in MM cells. In this study, we first examined protein expression of $\mathrm{I} \kappa \mathrm{B} \alpha$ after bortezomib treatment. We observed that bortezomib upregulated the phosphorylation and downregulated IкB $\alpha$ protein expression in a dose- and time-dependent manner in MCF7 and T47D cells, associated with phosphorylation of IKK $\beta$. Since I $\mathrm{K} B \alpha$ is an inhibitor of nuclear translocation of NF- $\mathrm{KB}$, we further examined alteration of NF- $\mathrm{KB}$ activity by bortezomib. Importantly, bortezomib significantly upregulates NF- $\mathrm{B}$ activity in both MCF7 and T47D in a dose-dependent fashion, demonstrated by electrophoretic mobility shift analysis (EMSA). Furthermore, immunocytochemical analysis confirmed enhanced nuclear translocation of p65 NF- $\mathrm{kB}$ (RelA) by bortezomib treatment. Supershift assay showed supershifted bands by anti-p65 and -p50 antibodies. Taken together, these results indicate that bortezomib activates the canonical NF- $\mathrm{KB}$ pathway in both cell lines. Finally, we demonstrated that IKK $\beta$ inhibitor
\end{abstract}

Correspondence to: Dr Teru Hideshima, Department of Medical Oncology, Dana-Farber Cancer Institute, 450 Brookline Avenue, Boston, MA 02215, USA

E-mail: teru_hideshima@dfci.harvard.edu

*Contributed equally

Key words: bortezomib, NF-кB, IKK $\beta$ inhibitor, breast cancer enhanced cytotoxicity, associated with inhibition of NF- $\mathrm{KB}$ activity induced by bortezomib in MCF7 and T47D breast cancer cells.

\section{Introduction}

Bortezomib is a reversible 26S proteasome inhibitor which was approved by the Food and Drug Administration in 2003, 2005 and 2008 for the treatment of relapsed/refractory, relapsed and newly diagnosed MM, respectively. The initial rationale to use bortezomib is inhibition of NF- $\kappa B$ activity, since NF- $\kappa B$ plays a crucial role in the pathogenesis in many types of cancer cells, including MM. The NF- $\kappa \mathrm{B}$ complex is typically a dimer comprised of different combinations of Rel family proteins, including p65 (RelA), RelB, c-Rel, p50 $(\mathrm{NF} \kappa \mathrm{B} 1)$, and $\mathrm{p} 52(\mathrm{NF \kappa} \mathrm{B} 2)$. Previous studies have revealed that NF- $\mathrm{KB}$ activity is mediated via two distinct, canonical and non-canonical, pathways (1-4). In the canonical pathway, $\mathrm{NF}-\kappa \mathrm{B}$ is typically a heterodimer composed of p50 and p65 subunits (5), and its activity is inhibited by association with ІкB family proteins (6). Following stimulation by various factors, I $\kappa$ brotein is phosphorylated by I $\kappa \mathrm{B}$ kinase (IKK), typically IKK $\beta$. Phosphorylated I $\kappa B$ is subsequently poly-ubiquitinated and degraded by the $26 \mathrm{~S}$ proteasome $(7,8)$, which allows p50/p65 NF- $\kappa \mathrm{B}$ nuclear translocation. Bortezomib inhibits degradation of $\mathrm{I} \kappa \mathrm{B} \alpha$ and therefore blocks NF- $\kappa \mathrm{B}$ activity.

Although bortezomib shows remarkable antitumor activities in preclinical (9-11) and clinical studies (12-14) in $\mathrm{MM}$, in most solid tumor populations, including breast cancer, bortezomib as monotherapy has not shown promising activity $(15,16)$. Bortezomib-based combination therapies have also been conducted using capecitabin (17), pegylated lisosomal doxorubicin (18), docetaxel (19) or paclitaxel (20). In these studies, 15 and $29 \%$ response rates were observed in combination with capecitabin and docetaxel, respectively.

However, importantly, recent studies have shown that bortezomib activates canonical NF- $\mathrm{KB}$ pathway both in vitro and in a human MM cell mouse xenograft model, associated with downregulation of I $\mathrm{B} \alpha$. Moreover, IKK $\beta$ inhibitors augment bortezomib-induced cytotoxicity (21). These results 
strongly suggest that $\mathrm{NF}-\kappa \mathrm{B}$ may not be a major target of bortezomib in the treatment of cancer cells. In this study, we therefore examined whether bortezomib also activates $\mathrm{NF}-\kappa \mathrm{B}$ activity in breast cancer cells, which may, at least in part, account for the insensitivity of these cells to bortezomib. Although constitutive NF- $\kappa \mathrm{B}$ activity was low, bortezomib significantly induced the canonical $N F-\kappa B$ pathway, which was blocked by IKK $\beta$ inhibitor, associated with enhanced cytotoxicity of bortezomib.

\section{Materials and methods}

Cells. T47D and MCF7 breast cancer cells as well as RPMI 8226 multiple myeloma cells were obtained from the ATCC (Manassas, VA). T47D and RPMI8226 cells were cultured in RPMI-1640 containing $10 \%$ fetal bovine serum (FBS, Sigma Chemical Co., St. Louis, MO), $2 \mu \mathrm{M}$ L-glutamine, $100 \mathrm{U} / \mathrm{ml}$ penicillin and $100 \mu \mathrm{g} / \mathrm{ml}$ streptomycin (Gibco-BRL, Grand Island, NY). MCF7 were cultured in Dulbecco's modified Eagle's medium with the above supplements.

Reagents. Bortezomib was purchased from Toronto Research Chemicals Inc. (North York, ON, Canada). IKK $\beta$ inhibitor BMS-345541 was purchased from Calbiochem (San Diego, CA).

Electrophoretic mobility shift analysis (EMSA). EMSA was carried out for detection of $\mathrm{NF}-\kappa \mathrm{B}$ activity, as previously reported (4). Briefly, nuclear extracts from MM cells were obtained using Nuclear Extraction Kit ${ }^{\circledR}$ (Panomics, Fremont, CA). Double-stranded NF- $\kappa$ B oligonucleotide probe (Promega, Madison, WI) were end-labeled with $\left[\gamma^{32} \mathrm{P}\right]$ ATP $(10 \mathrm{mCi} / \mathrm{ml}$, Perkin-Elmer, Boston, MA). Binding reactions containing $0.035 \mathrm{pmol} / \mu \mathrm{l}$ of oligonucleotide and $10 \mu \mathrm{g}$ of nuclear protein were conducted at room temperature for $30 \mathrm{~min}$ in binding buffer (10 mM Tris- $\mathrm{HCl}$, pH 7.5, $50 \mathrm{mM} \mathrm{NaCl}, 1 \mathrm{mM} \mathrm{MgCl}$, $0.5 \mathrm{mM}$ EDTA, $0.5 \mathrm{mM}$ DTT, $4 \%$ glycerol (v/v) and $0.5 \mu \mathrm{g}$ poly (dI-dC) (Pharmacia, Peapack, NJ). The samples were loaded onto a $4 \%$ polyacrylamide gel, transferred to Whatman paper (Whatman International, Maidstone, UK) and visualized by autoradiography. For supershift analysis, $1 \mu \mathrm{g}$ of anti-p65, RelB, c-Rel (Santa Cruz Biotechnology, Santa Cruz, CA), p50 (Abcam, Cambridge, MA) or p52 (Rockland, Gilbertsville, PA) Abs were incubated for 5 min prior to adding the reaction mixtures.

Cell proliferation assay. The inhibitory effect of bortezomib, alone or combined with BMS-345541, on cell growth was assessed by measuring 3-(4,5-dimethylthiazol-2-yl)-2,5-diphenyl tetrasodium bromide (MTT, Chemicon International, Temecula, CA) dye absorbance. Cells were pulsed with $10 \mu \mathrm{l}$ of $5 \mathrm{mg} / \mathrm{ml} \mathrm{MTT} \mathrm{to} \mathrm{each} \mathrm{well} \mathrm{for} \mathrm{the} \mathrm{last} 4$ of 24 - and/or 48 -h cultures, followed by $100 \mu \mathrm{l}$ isopropanol containing $0.04 \mathrm{~N} \mathrm{HCl}$. Absorbance was measured at 570/630 nm using a spectrophotometer (Molecular Devices Corp., Sunnyvale, CA). All experiments were performed 3 times in quadruplicate.

Immunoblot analysis. MM cells were harvested and lysed using lysis buffer: $50 \mathrm{mM}$ Tris- $\mathrm{HCl}$ (pH 7.4), $150 \mathrm{mM} \mathrm{NaCl}$, $1 \%$ NP-40, 5 mM EDTA, $5 \mathrm{mM} \mathrm{NaF,} 2 \mathrm{mM} \mathrm{Na}_{3} \mathrm{VO}_{4}, 1 \mathrm{mM}$ PMSF, $5 \mu \mathrm{g} / \mathrm{ml}$ leupeptine and $5 \mu \mathrm{g} / \mathrm{ml}$ aprotinin. Whole cell lysates were subjected to SDS-PAGE and transferred to PVDF membrane (Bio-Rad Laboratories, Hercules, CA). The Abs used for immunoblot analysis included: anti-phospho (p)-RIP2 (Ser176), p-IKK $\alpha / \beta$ (ser176/180), p-p65 (Ser536), p-IкB $\alpha$

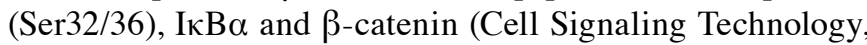
Danvers, MA); as well as anti-RIP2, p65, p50, p52, RelB and GAPDH (Santa Cruz Biotechnology) Abs.

Immunofluorescence. Immunostaining was carried out according to the manufacturer's protocol. Briefly, T47D cells were cultured for $24 \mathrm{~h}$ on Lab-Tek ${ }^{\circledR}$ II Chamber Slide System (Thermo Fisher Scientific, Rochester, NY) prior to bortezomib treatment. T47 cells were then treated with $10 \mathrm{nM}$ Bortezomib for $16 \mathrm{~h}$, fixed with $2 \%$ formaldehyde-PBS and $100 \%$ methanol. After blocking with 5\% rabbit serum-PBS for $1 \mathrm{~h}$, slides were incubated overnight with anti-p65 NF- $\mathrm{B}$ Ab (Cell Signaling Technology, Danvers, MA). Cells were then washed and incubated with fluorescence in isothiocyanate-conjugated goat anti-rabbit IgG. Slides were analyzed using Yokogawa spinning disk confocal/TIRE system with Nikon inverted Ti microscope.

Statistical analysis. Statistical significance of differences observed in drug-treated versus control cultures was determined using the Wilcoxon signed-rank test. The minimal level of significance was $\mathrm{p}<0.05$.

\section{Results}

MCF7 and T47D cells are relatively resistant to bortezomib treatment. We first examined sensitivity of MCF7 and T47D cells to bortezomib treatment. MCF7 and T47D cells were cultured in the presence of different concentration of bortezomib (up to $80 \mathrm{nM}$ ) for 24 (Fig. 1A) and $48 \mathrm{~h}$ (Fig. 1B). RPMI8226 MM cells were employed as positive control of bortezomib treatment. Compared to RPMI8226, MCF7 and T47D cells were relatively resistant to bortezomib. Especially, bortezomib could not reach the $\mathrm{IC}_{50}$ growth inhibition dose in MCF7 cells in this setting.

Bortezomib downregulates the I $\kappa$ B $\alpha$ protein. We next examined expression of $\mathrm{I} \kappa \mathrm{B} \alpha$ and other Rel family member proteins (p50, p52, p65, RelB) in both MCF7 and T47D cells before and after bortezomib treatment. Similar to MM cells (21), bortezomib induced phosphorylation and downregulation of $\mathrm{I} \kappa \mathrm{B} \alpha$ in both MCF7 and T47D cells after 8-h treatment without alteration of other Rel family member proteins. Interestingly, this effect was more pronounced in T47D cells than in MCF7 cells (Fig. 2A). However, time-dependent study demonstrated that phosphorylation and downregulation of $\mathrm{I} \kappa \mathrm{B} \alpha$ were similarly observed in both cell lines after 16-h treatment with bortezomib (Fig. 2B). These results strongly suggest bortezomib may activate the canonical $\mathrm{NF}-\kappa \mathrm{B}$ activity.

Bortezomib triggers $N F-\kappa B$ activation associated with enhanced p65 (RelA) nuclear translocation. Since $\mathrm{I} \kappa \mathrm{B} \alpha$ is an inhibitor of nuclear translocation of p50/p65 heterodimer, we next examined whether bortezomib triggered $N F-\kappa B$ activation in breast cancer cells. To obtain direct evidence showing $\mathrm{NF}-\kappa \mathrm{B}$ activation by bortezomib, we carried out EMSA. 
A

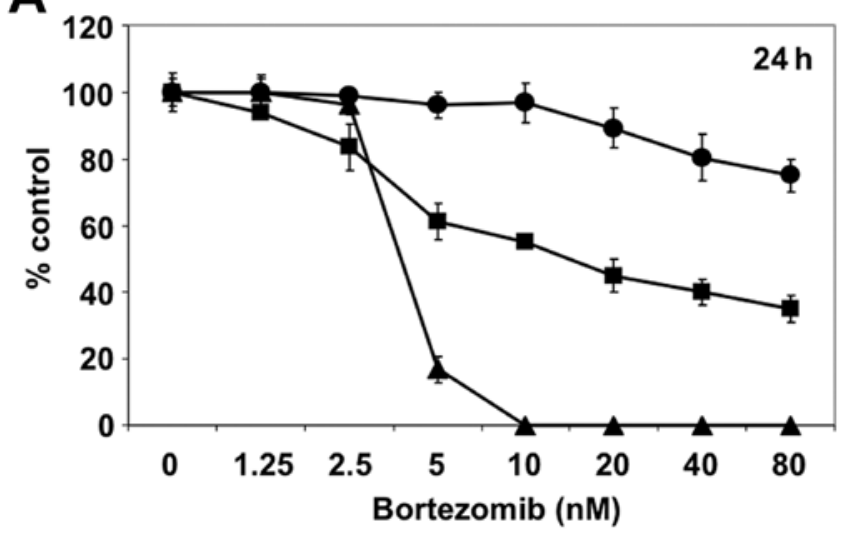

B

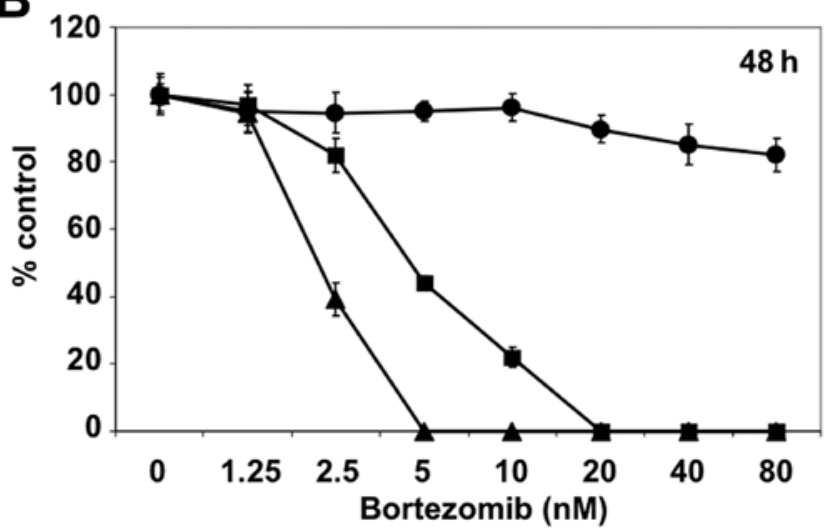

Figure 1. Breast cancer cell lines are relatively resistant to bortezomib treat-

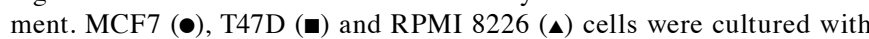
bortezomib (1.25-80 $\mathrm{nM}$ ) for (A) 24 and (B) $48 \mathrm{~h}$, and cell growth was assessed by MTT assay.

Consistent with downregulation of I $\kappa \mathrm{B} \alpha$, bortezomib markedly enhanced $\mathrm{NF}-\kappa \mathrm{B}$ activity in a dose-dependent fashion in MCF7 and T47D cells (Fig. 3A). We further examined nuclear p65 expression in T47D cells by immunocytochemistry and confirmed that bortezomib markedly enhanced nuclear translocation of p65 (Fig. 3B). These results indicated that NF- $\mathrm{BB}$ was activated by bortezomib treatment in breast cancer cells.

Bortezomib activates the canonical $N F-\kappa B$ pathway in breast cancer cell lines. NF- $\mathrm{B}$ activation is mediated via both canonical and non-canonical pathways, and we further examined whether $\mathrm{NF}-\kappa \mathrm{B}$ activation by bortezomib was solely via canonical NF- $\kappa \mathrm{B}$ activation, since $\mathrm{I} \kappa \mathrm{B} \alpha$ is a major inhibitor of p50/65 nuclear translocation. Supershift assays confirmed that bortezomib triggered canonical $\mathrm{NF}-\kappa \mathrm{B}$ activation, evidenced by markedly enhanced supershifted bands in the presence of anti-p65 and p50, but not p52 or RelB (RB) Abs in T47D cells (Fig. 4). This result, strongly indicating that bortezomib triggers activation of the canonical NF- $\kappa \mathrm{B}$ pathway.

Inhibition of IKK $\beta$ blocks bortezomib-induced I $\kappa$ B $\alpha$ downregulation and $N F-\kappa B$ activation. Since bortezomib-triggered $\mathrm{NF}-\kappa \mathrm{B}$ canonical activation is mediated via phosphorylation and downregulation of $\mathrm{I} \kappa \mathrm{B} \alpha$, we next examined whether inhibition of upstream molecule blocked bortezomib-induced $\mathrm{NF}-\kappa \mathrm{B}$ activation. T47D cells were cultured with bortezomib
A

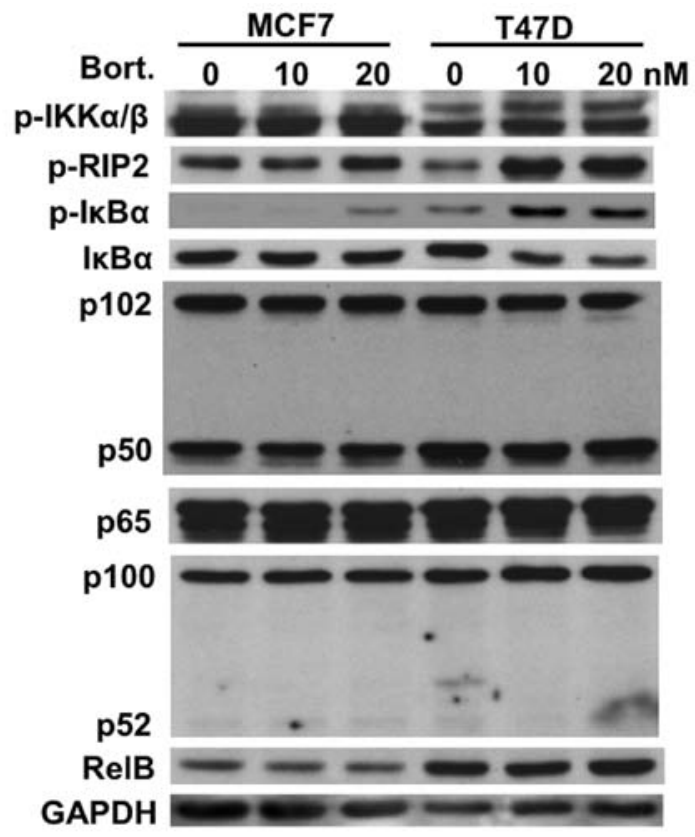

B
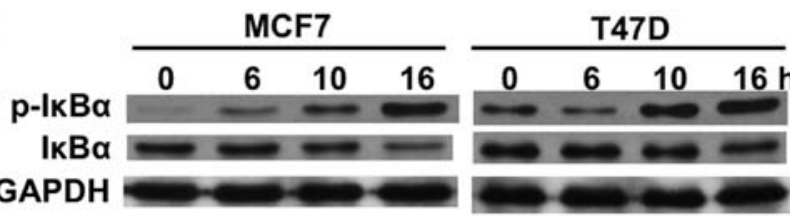

Figure 2. Bortezomib downregulates I $\mathrm{B} \alpha$ expression. (A) MCF7 and T47D cells were cultured with bortezomib (10 and $20 \mathrm{nM})$ for $8 \mathrm{~h}$. Whole cell lysates were subjected to western blot analysis using indicated antibodies. (B) MCF7 and T47D cells were cultured with bortezomib (10 nM) for the indicated time periods. Whole cell lysates were subjected to western blot analysis using indicated antibodies.

in the presence and absence of IKK $\beta$ inhibitor BMS-345541. BMS-345541 inhibited both phosphorylation and protein expression of $\mathrm{I} \kappa \mathrm{B} \alpha$ (Fig. 5A, upper panel). Importantly, NF- $\kappa \mathrm{B}$ activation induced by bortezomib was completely blocked by BMS-345541 (Fig. 5A, lower panel), suggesting that activation of IKK $\beta$ plays a key role in bortezomib-induced $N F-\kappa B$ activation. Moreover, inhibition of canonical NF- $\kappa \mathrm{B}$ activity by BMS-345541 enhanced bortezomib-induced cytotoxicity in T47D cells (Fig. 5B).

\section{Discussion}

$\mathrm{NF}-\kappa \mathrm{B}$ is a transcriptional factor of the Rel family proteins, including p65 (RelA), RelB, c-Rel, p50 (NF-кB1) and p52 (NFא-B2), which regulates cell proliferation, anti-apoptosis and cytokine secretion in many cancers (22). In canonical pathway, $\mathrm{NF}-\kappa \mathrm{B}$ is typically a heterodimer composed of $\mathrm{p} 50$ and p65 subunits and constitutively present both in the cytosol and nucleus. In the cytosol, p50/p65 nuclear translocation is blocked by $\mathrm{I} \kappa \mathrm{B}$ family inhibitors; I $\kappa \mathrm{B} \alpha$ therefore has a crucial role in regulating $\mathrm{NF}-\kappa \mathrm{B}$ activation (23). Upon stimulation by various types of growth factors and cytokines (i.e., $\mathrm{TNF} \alpha$ ), I $\kappa \mathrm{B} \alpha$ is phosphorylated by the upstream molecules, $\mathrm{I} \kappa \mathrm{B}$ kinases (IKKs). I $\kappa \mathrm{B} \alpha$ is subsequently polyubiquitinated 
A

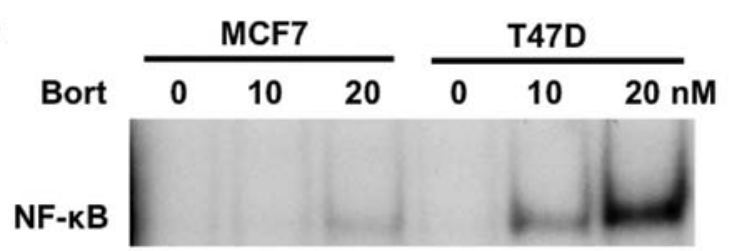

B
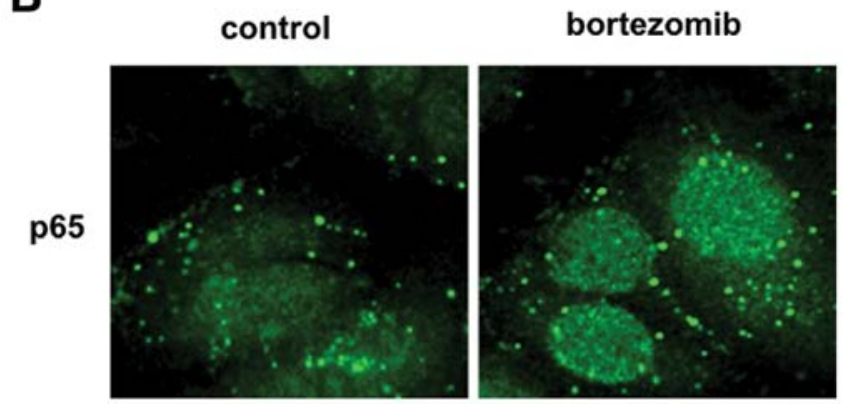

DAPI
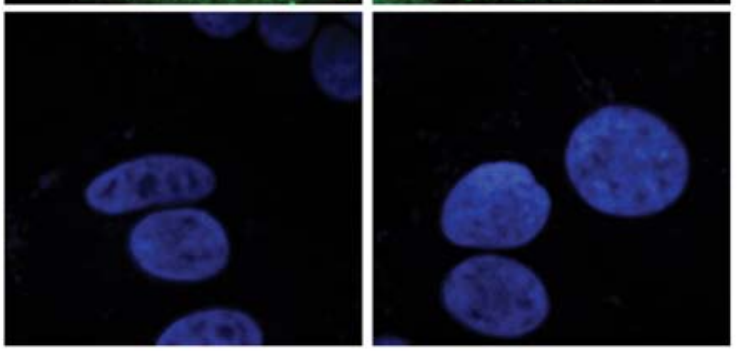

Figure 3. Bortezomib triggers NF- $\kappa \mathrm{B}$ activation associated with enhanced p65 (RelA) nuclear translocation. (A) MCF7 and T47D cells were cultured with increasing doses of bortezomib (10-20 nM) of bortezomib or control media for $12 \mathrm{~h}$. Nuclear protein was extracted and subjected to EMSA. (B) T47D cells were cultured with bortezomib $(10 \mathrm{nM})$ or control media for $12 \mathrm{~h}$. Cells were subjected to immunostaining using anti-p65 NF-kB (green) and DAPI (blue) followed by confocal microscopic analysis.

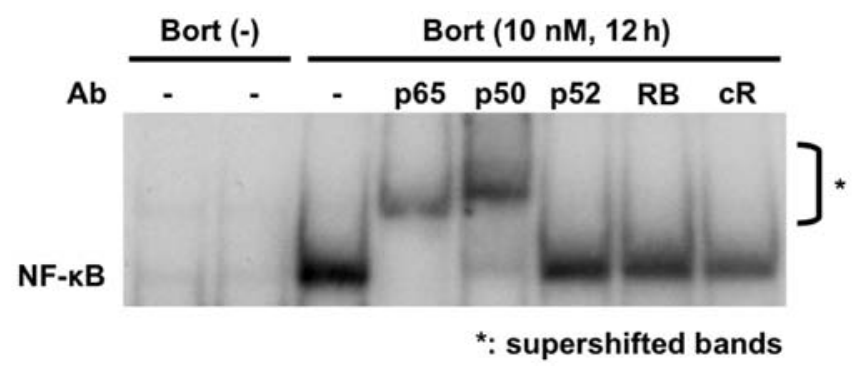

Figure 4. Bortezomib activates the canonical NF- $\kappa \mathrm{B}$ pathway. T47D cells were cultured with bortezomib $(10 \mathrm{nM})$ or control media for $12 \mathrm{~h}$. Nuclear extracts from the cells were subjected to supershift assay, using anti-p65, anti-p50, anti-p52 and anti-RelB antibodies.

and degraded by proteasome, allowing nuclear translocation of p50/65, where it binds to specific DNA sequences in the promoters of target genes.

Bortezomib is a $26 \mathrm{~S}$ proteasome inhibitor initially used in MM treatment based upon expectation that bortezomib could inhibit NF- $\kappa \mathrm{B}$ activity by preventing proteasomal degradation of IкB $\alpha$. It demonstrates remarkable anti-MM activities in both preclinical (9-11) and clinical (12-14) studies, and was

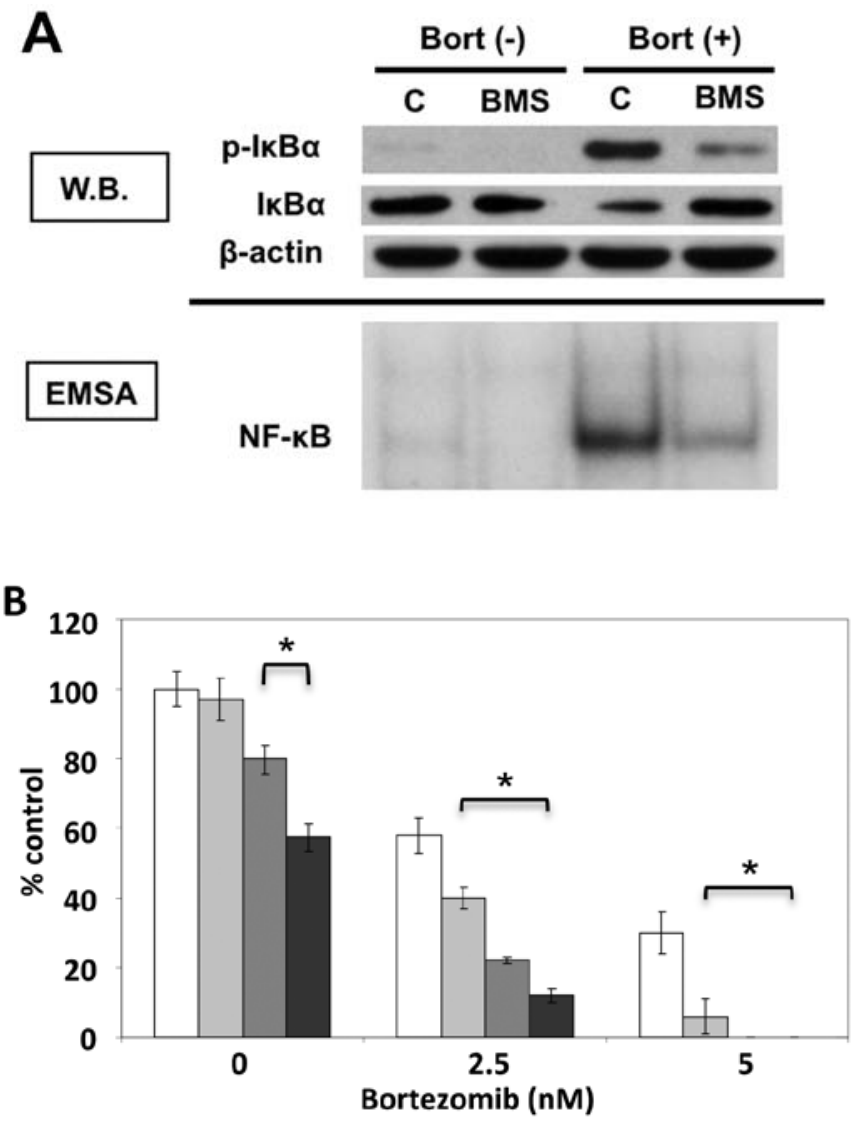

Figure 5. Inhibition of IKK $\beta$ blocks bortezomib-induced $\mathrm{I}_{\kappa} \mathrm{B} \alpha$ downregulation and NF- $\kappa \mathrm{B}$ activation. (A) T47D cells were cultured with bortezomib (10 nM) or control media in the presence or absence of BMS-345541 $(10 \mu \mathrm{M})$ for $12 \mathrm{~h}$ and nuclear extracts were subjected to EMSA. Cytoplasmic protein was also immuoblotted with $\mathrm{p}$-I $\mathrm{B} \mathrm{B} \alpha, \mathrm{I} \kappa \mathrm{B} \alpha$ and $\beta$-actin. (B) T47D cells were cultured with bortezomib (2.5 and $5 \mathrm{nM}$ ) in the presence of $2.5 \mu \mathrm{M}$ (light grey), $5 \mu \mathrm{M}$ (dark grey) or $10 \mu \mathrm{M}$ (black) of BMS-345541 for $24 \mathrm{~h}$, and cell growth was assessed by MTT assay. " $\mathrm{p}<0.01$ vs control.

approved by FDA in 2003 for therapy of relapsed refractory MM, in 2005 for treatment of relapsed MM, and in 2008 for initial treatment in MM. Although extensive molecular-based studies have been done in MM, inhibition of constitutive $\mathrm{NF}-\kappa \mathrm{B}$ activity by bortezomib has not been shown in either preclinical or clinical studies. However, in most solid tumors, including breast cancer, bortezomib, as monotherapy, has not shown promising antitumor activity $(15,16)$. Importantly, recent studies have shown that bortezomib activates constitutive NF- $\kappa \mathrm{B}$ in endothelial cell carcinoma cells (24) and in primary tumor cells from MM patients $(21,25)$, suggesting that inhibition of NF- $\mathrm{kB}$ does not solely account for its antitumor activities. In this study, we therefore examined whether bortezomib also modulates constitutive NF- $\mathrm{KB}$ activity regulating cell proliferation and anti-apoptosis in breast cancer cells.

To determine the optimal dose of bortezomib to assess NF- $\kappa \mathrm{B}$ activity, we first examined sensitivity of MCF7 and T47D to bortezomib treatment and observed that breast cancer lines, especially MCF7, were relatively resistant to bortezomib. Previous studies have shown that heat shock protein $27(26,27)$ and proteasome subunit $\beta 5$ (PSMB5) gene mutation and overexpression of PSMB5 protein decrease sensitivity to bortezomib in MM and myelomonocytic THP1 
cells, respectively (28). However, the mechanisms of action decreasing the sensitivity to bortezomib in these breast cancer cell lines remain unclear.

It has been shown that bortezomib inhibits proteasomal degradation of $\mathrm{I} \kappa \mathrm{B} \alpha$ induced by cytokines (i.e., TNF $\alpha$ ) (29); however, I $\mathrm{B} \alpha$ was downregulated in both cell lines by bortezomib treatment, associated with enhanced phosphorylation in breast cancer cells. These results are similar to previous studies observed in MM cells (21). Since $\mathrm{I} \kappa \mathrm{B} \alpha$ regulates the canonical NF- $\kappa \mathrm{B}$ pathway, we further examined $\mathrm{NF}-\kappa \mathrm{B}$ activity in MCF7 and T47D cells after bortezomib treatment. Although constitutive $\mathrm{NF}-\kappa \mathrm{B}$ activity was extremely low, bortezomib markedly enhanced $N F-\kappa B$ activity in a dose-dependent fashion. This result was consistent to downregulated protein level of $\mathrm{I} \kappa \mathrm{B} \alpha$ by bortezomib. Interestingly, bortezomib-induced NF- $\kappa \mathrm{B}$ activity in T47D was more significant than that in MCF7 cells. As described above, MCF7 cells are more resistant to bortezomib compared to T47D, these results suggested that $\mathrm{NF}-\kappa \mathrm{B}$ activation may not be totally responsible for resistance to bortezomib in these breast cancer cell lines.

Since NF- $\kappa \mathrm{B}$ mediates cell survival and progression of disease in breast cancer $(30,31)$, we hypothesized that the blockade of bortezomib-induced canonical NF- $\kappa \mathrm{B}$ activation could enhance its growth inhibitory effect. Indeed, previous study has shown that doxorubicin activates the $N F-\kappa B$ and that inhibition of IKK sensitizes breast cancer cells to bortezomib (32). As expected, IKK $\beta$ inhibitor almost completely blocked bortezomib-induced $N F-\kappa B$ activation and significantly augmented its cytotoxicity. Taken together our results provide the preclinical framework for combination strategy of bortezomib with other agents inhibiting IKK $\beta$.

\section{Acknowledgements}

This study was supported by the National Institute of Health Grants (SPORE-P50100707, P01 CA78378 and R01 CA50947; to K.C.A.).

\section{References}

1. Jost PJ and Ruland J: Aberrant NF- $\kappa \mathrm{B}$ signaling in lymphoma: mechanisms, consequences, and therapeutic implications. Blood 109: 2700-2707, 2007.

2. Keats JJ, Fonseca R, Chesi M, Schop R, Baker A, Chng WJ, Van Wier S, Tiedemann R, Shi CX, Sebag M, Braggio E, Henry T, et al: Promiscuous mutations activate the noncanonical NF- $\mathrm{NB}$ pathway in multiple myeloma. Cancer Cell 12: 131-144, 2007.

3. Annunziata CM, Davis RE, Demchenko Y, Bellamy W, Gabrea A, Zhan F, Lenz G, Hanamura I, Wright G, Xiao W, Dave S, Hurt EM et al: Frequent engagement of the classical and alternative $\mathrm{NF}-\kappa \mathrm{B}$ pathways by diverse genetic abnormalities in multiple myeloma. Cancer Cell 12: 115-130, 2007.

4. Hideshima T, Chauhan D, Kiziltepe T, Ikeda H, Okawa Y, Podar K, Raje N, Protopopov A, Munshi NC, Richardson PG, Carrasco RD and Anderson $\mathrm{KC}$ : Biologic sequelae of $\mathrm{I} \kappa \mathrm{B}$ kinase (IKK) inhibition in multiple myeloma: therapeutic implications. Blood 113: 5228-5236, 2009.

5. Baldwin AS Jr: The NF- $\kappa$ B and I $\mathrm{B}$ proteins: new discoveries and insights. Annu Rev Immunol 14: 649-683, 1996.

6. Beg AA and Baldwin AS Jr: The IкB proteins: multifunctional regulators of Rel NF- $\kappa$ B transcription factors. Genes Dev 7: 2064-2070, 1993.

7. Zandi E, Chen Y and Karin M: Direct phosphorylation of IkappaB by IKK $\alpha$ and IKK $\beta$ : discrimination between free and NF-кB-bound substrate. Science 281: 1360-1363, 1998.
8. DiDonato JA, Hayakawa M, Rothwarf DM, Zandi E and Karin M: A cytokine-responsive I $\mathrm{B}$ kinase that activates the transcription factor $\mathrm{NF}-\kappa \mathrm{B}$. Nature 388: 548-554, 1997.

9. Hideshima T, Richardson P, Chauhan D, Palombella V, Elliott P, Adams J and Anderson KC: The proteasome inhibitor PS-341 inhibits growth, induces apoptosis and overcomes drug resistance in human multiple myeloma cells. Cancer Res 61: 3071-3076, 2001.

10. Mitsiades N, Mitsiades CS, Poulaki V, Chauhan D, Fanourakis G, Gu X, Bailey C, Joseph M, Libermann TA, Treon SP, Munshi NC, Richardson PG, et al: Molecular sequelae of proteasome inhibition in human multiple myeloma cells. Proc Natl Acad Sci USA 99: 14374-14379, 2002.

11. Hideshima T, Mitsiades C, Akiyama M, Hayashi T, Chauhan D, Richardson P, Schlossman R, Podar K, Munshi NC, Mitsiades N and Anderson KC: Molecular mechanisms mediating antimyeloma activity of proteasome inhibitor PS-341. Blood 101: 1530-1534, 2003.

12. Richardson PG, Barlogie B, Berenson J, Singhal S, Jagannath S, Irwin D, Rajkumar SV, Srkalovic G, Alsina M, Alexanian R, Siegel D, Orlowski RZ, et al: A phase 2 study of bortezomib in relapsed, refractory myeloma. N Engl J Med 348: 2609-2617, 2003.

13. Richardson PG, Sonneveld P, Schuster MW, Irwin D, Stadtmauer EA, Facon T, Harousseau JL, Ben-Yehuda D, Lonial S, Goldschmidt H, Reece D, San-Miguel JF, et al: Bortezomib or high-dose dexamethasone for relapsed multiple myeloma. N Engl J Med 352: 2487-2498, 2005.

14. San Miguel JF, Schlag R, Khuageva NK, Dimopoulos MA, Shpilberg O, Kropff M, Spicka I, Petrucci MT, Palumbo A, Samoilova OS, Dmoszynska A, Abdulkadyrov KM, et al: Bortezomib plus melphalan and prednisone for initial treatment of multiple myeloma. N Engl J Med 359: 906-917, 2008.

15. Engel RH, Brown JA, Von Roenn JH, O'Regan RM, Bergan R, Badve S, Rademaker A and Gradishar WJ: A phase II study of single agent bortezomib in patients with metastatic breast cancer: a single institution experience. Cancer Invest 25: 733-737, 2007.

16. Dees EC, Orlowski RZ. Targeting the ubiquitin-proteasome pathway in breast cancer therapy. Future Oncol 2: 121-135, 2006

17. Schmid P, Kuhnhardt D, Kiewe P, Lehenbauer-Dehm S, Schippinger W, Greil R, Lange W, Preiss J, Niederle N, Brossart P, Freier W, Kummel S, et al: A phase I/II study of bortezomib and capecitabine in patients with metastatic breast cancer previously treated with taxanes and/or anthracyclines. Ann Oncol 19: 871-876, 2008 .

18. Dees EC, O'Neil BH, Lindley CM, Collichio F, Carey LA, Collins J, Riordan WJ, Ivanova A, Esseltine D and Orlowski RZ: A phase I and pharmacologic study of the combination of bortezomib and pegylated liposomal doxorubicin in patients with refractory solid tumors. Cancer Chemother Pharmacol 63: 99-107, 2008.

19. Awada A, Albanell J, Canney PA, Dirix LY, Gil T, Cardoso F, Gascon P, Piccart MJ and Baselga J: Bortezomib/docetaxel combination therapy in patients with anthracycline-pretreated advanced/metastatic breast cancer: a phase I/II dose-escalation study. Br J Cancer 98: 1500-1507, 2008.

20. Cresta S, Sessa C, Catapano CV, Gallerani E, Passalacqua D, Rinaldi A, Bertoni F, Vigano L, Maur M, Capri G, Maccioni E, Tosi D, et al: Phase I study of bortezomib with weekly paclitaxel in patients with advanced solid tumours. Eur J Cancer 44: 1829-1834, 2008

21. Hideshima T, Ikeda H, Chauhan D, Okawa Y, Raje N, Podar K, Mitsiades C, Munshi NC, Richardson PG, Carrasco RD and Anderson KC: Bortezomib induces canonical nuclear factor- $\kappa \mathrm{B}$ activation in multiple myeloma cells. Blood 114: 1046-1052, 2009.

22. Karin M and Greten FR: NF-kappaB: linking inflammation and immunity to cancer development and progression. Nat Rev Immunol 5: 749-759, 2005.

23. Karin M and Ben-Neriah Y: Phosphorylation meets ubiquitination: the control of NF- $\kappa \mathrm{B}$ activity. Annu Rev Immunol 18: 621-663, 2000.

24. Dolcet X, Llobet D, Encinas M, Pallares J, Cabero A, Schoenenberger JA, Comella JX and Matias-Guiu X: Proteasome inhibitors induce death but activate $\mathrm{NF}-\kappa \mathrm{B}$ on endometrial carcinoma cell lines and primary culture explants. J Biol Chem 281: 22118-22130, 2006.

25. Markovina S, Callander NS, O'Connor SL, Kim J, Werndli JE, Raschko M, Leith CP, Kahl BS, Kim K and Miyamoto S: Bortezomib-resistant nuclear factor- $\kappa \mathrm{B}$ activity in multiple myeloma cells. Mol Cancer Res 6: 1356-1364, 2008. 
26. Chauhan D, Li G, Shringarpure R, Podar K, Ohtake Y, Hideshima T and Anderson KC: Blockade of Hsp27 overcomes Bortezomib/proteasome inhibitor PS-341 resistance in lymphoma cells. Cancer Res 63: 6174-6177, 2003.

27. Hideshima T, Podar K, Chauhan D, Ishitsuka K, Mitsiades C, Tai YT, Hamasaki M, Raje N, Hideshima H, Schreiner G, Nguyen AN, Navas T, et al: p38 MAPK inhibition enhances PS-341 (bortezomib)-induced cytotoxicity against multiple myeloma cells. Oncogene 23: 8766-8776, 2004.

28. Oerlemans R, Franke NE, Assaraf YG, Cloos J, van Zantwijk I, Berkers CR, Scheffer GL, Debipersad K, Vojtekova K, Lemos C, van der Heijden JW, Ylstra B, et al: Molecular basis of bortezomib resistance: proteasome subunit beta5 (PSMB5) gene mutation and overexpression of PSMB5 protein. Blood 112: 2489-2499, 2008.
29. Hideshima T, Chauhan D, Richardson P, Mitsiades C, Mitsiades N, Hayashi T, Munshi N, Dang L, Castro A, Palombella V, Adams J, Anderson KC. NF-kB as a therapeutic target in multiple myeloma. J Biol Chem 277: 16639-16647, 2002.

30. Garg AK, Hortobagyi GN, Aggarwal BB, Sahin AA and Buchholz TA: Nuclear factor- $\kappa \mathrm{B}$ as a predictor of treatment response in breast cancer. Curr Opin Oncol 15: 405-411, 2003.

31. Wu JT and Kral JG: The NF- $\kappa \mathrm{B} / \mathrm{I} \kappa \mathrm{B}$ signaling system: a molecular target in breast cancer therapy. J Surg Res 123: 158-169, 2005.

32. Tapia MA, Gonzalez-Navarrete I, Dalmases A, Bosch M, Rodriguez-Fanjul V, Rolfe M, Ross JS, Mezquita J, Mezquita C, Bachs O, Gascon P, Rojo F, et al: Inhibition of the canonical IKK/NF $\kappa \mathrm{B}$ pathway sensitizes human cancer cells to doxorubicin. Cell Cycle 6: 2284-2292, 2007. 